7. Reprod. Fert. (1975) 45, 567-574

\title{
THE FUNCTION OF THE GROWING FOLLICLE
}

\author{
B. LUNENFELD, Z. KRAIEM AND ALIZA ESHKOL \\ Institute of Endocrinology, The Chaim Sheba Medical Center, Tel-Hashomer, and \\ Department of Life Sciences, Bar-Ilan University, Israel
}

Summary. The follicle plays a major role in the dual function of the ovary-oocyte maturation and release and steroidogenesis required for regulating its own growth and providing the proper environment in reproductive organs for the transport of gametes and nidation. Some aspects of how follicles attain their functional competence following a series of developmental changes are discussed. The presentation is based on data obtained mainly in rodents in which follicular development occurs postnatally.

The peak activity of follicular growth occurs during the 1st week of life, but not until the 5th day is follicular development clearly dependent upon gonadotrophin stimulation. The formation of the theca layer and zona pellucida, differentiation of the vascular system and competence to respond to gonadotrophins are acquired during the 2nd week. FSH alone is primarily responsible for granulosa cell proliferation and the integrity of the granulosa cell membrane, but has little differential effect on steroidogenic enzymes. Synergism of FSH and LH promotes an enrichment of the theca layer, enhancement of vascular development and antrum formation, and induces a marked differential stimulation of $20 \alpha$-hydroxysteroid dehydrogenase, aromatizing and cholesterol side-chain cleavage systems.

The number of gonadotrophin receptors on granulosa and theca cells increases with follicular development. Steroids secreted by the ovary seem to modulate follicular growth, not only by effects upon FSH and $\mathrm{LH}$ release but also by a local influence within the ovary. A number of physiological events related to follicular function are explained according to these observations.

\section{INTRODUCTION}

The follicle is the major ovarian compartment which enables the ovary to fulfill its dual function of gametogenesis and steroidogenesis. The follicular apparatus provides the necessary environment for maturation and release of the ovum. It also produces the steroid hormones that regulate its own growth and stimulate the reproductive organs to enable transport of gametes and nidation of the fertilized ovum.

Follicles acquire functional competence progressively as they mature 
following a series of developmental changes. In the present discussion, we describe some aspects of this process and its regulatory factors, as well as some of the functional interactions between the different compartments of the follicle, i.e. the oocyte, granulosa and thecal cells.

The kinetics of ovarian follicular development and responsiveness to gonadotrophic stimulation can best be analysed if followed from the earliest stage onwards. For this reason an animal model in which this development occurs postnatally, as in the mouse, is more convenient than one in which follicular development is influenced by both maternal and fetal environments, as in the human (Witschi, 1963). We shall therefore mainly concentrate on results obtained from rodent studies.

THE FOLLICLE DURING THE FIRST WEEK OF LIFE

The mouse ovary at birth consists mainly of small oocytes lying close together in clusters surrounded by stroma cells. By the age of 7 days follicles can be seen with one or two rows of granulosa cells surrounding the oocyte. Byskov \& Lintern-Moore (1973) have suggested that the cells which in the early neonatal period become attached to the surface of oocytes and form the granulosa cells are derived from cells of the intraovarian rete cords. The first week of life is also the period of peak activity of follicular growth, regarding both the number of follicles starting the process (Pedersen, 1969) and the speed with which follicles grow (Pedersen, 1972).

Two intraovarian factors have been demonstrated to influence the initiation of follicular growth, i.e. the signal for the oocyte to begin growth and for granulosa cells to start multiplying. One is the size of the pool of non-growing small follicles: a reduction in the size of the pool, as occurs with maturation, causes fewer follicles to start growing (Krarup et al., 1969). Oocytes leaving the ovary through the surface epithelium, which occurs mainly during the first week of life, seems to be the most common mechanism to reduce the pool of non-growing follicles (Byskov \& Rasmussen, 1973). The other factor regulating the initiation of follicular growth is the degeneration of large follicles which apparently release a substance that restrains initiation of follicular development (Peters $e t$ al., 1973). Here again, with advancing age, the increased number of degenerating follicles gradually reduces initiation of follicular growth.

Dependence of normal follicular development upon gonadotrophic stimulation, though indicative on the 5th day of life, becomes unquestionable from Day 7 onwards. This has been shown in experiments in which deprivation of endogenous gonadotrophins is achieved by means of daily antiserum administration continuously from birth (Lunenfeld \& Eshkol, 1970). Only after 8 days of such treatment was a significant retardation in follicular development observed in ultrastructural studies (Stegner et al., 1970), confirming earlier findings using light microscopy and analyses of differential counts of follicles (Eshkol et al., 1970). As shown in Table 1, although the total number of growing follicles remained unchanged, follicular development in gonadotrophindeprived animals hardly progressed beyond the 40-cell stage. 
THE FOLLICLE DURING THE SECOND WEEK OF LIFE

A number of events occur during the 2nd week of life: development to the stage of multilayered follicles; formation of the theca layer; appearance of the zona pellucida; and differentiation of the vascular system with blood vessels penetrating the thecal layer. Competence of ovarian adenyl cyclase to respond to LH, and of ovarian protein kinase to respond to cyclic AMP (Lamprecht et al., 1973), as well as the capacity to increase the rate of protein synthesis following FSH and LH stimulation (Schneider \& Ben-Or, 1973), are also acquired during the 2 nd week of life.

Table 1. The mean number of follicles in ovaries of mice subjected to various treatments at 7 days or 14 days of age

\begin{tabular}{|c|c|c|c|c|c|c|}
\hline & \multicolumn{5}{|c|}{ No. of granulosa cells in largest cross-section of follicle } & \multirow{2}{*}{ Total } \\
\hline & $10-20$ & $21-40$ & $41-60$ & $61-100$ & $>100$ & \\
\hline $\begin{array}{l}\text { (a) } 7 \text {-day-old mice } \\
\text { Control } \\
\text { aRG } \\
\text { aRG +FSH } \\
\text { aRG + HMG } \dagger\end{array}$ & $\begin{array}{l}42 \cdot 5 \\
81 \cdot 3 \\
68 \cdot 4 \\
61 \cdot 2\end{array}$ & $\begin{array}{r}62 \cdot 6 \\
90 \cdot 5 \\
118 \cdot 8 \\
122 \cdot 4\end{array}$ & $\begin{array}{r}41 \cdot 0 \\
2 \cdot 0 \\
46 \cdot 8 \\
55 \cdot 8\end{array}$ & $\begin{array}{c}16 \cdot 6 \\
0 \\
14 \cdot 4 \\
16 \cdot 2\end{array}$ & $\begin{array}{l}2 \cdot 9 \\
0 \\
0 \\
0\end{array}$ & $\begin{array}{l}165 \cdot 6 \\
173 \cdot 8 \\
248 \cdot 4 \ddagger \\
255 \cdot 6 \ddagger\end{array}$ \\
\hline $\begin{array}{l}\text { (b) 14-day-old mice } \\
\text { Control } \\
\text { aRG } \\
\text { aRG +FSH } \\
\text { aRG + HMG } \dagger\end{array}$ & $\begin{array}{l}40 \cdot 8 \\
33 \cdot 3 \\
77 \cdot 4 \\
59 \cdot 4\end{array}$ & $\begin{array}{l}54 \cdot 9 \\
69 \cdot 3 \\
54 \cdot 0 \\
57 \cdot 6\end{array}$ & $\begin{array}{c}50 \cdot 4 \\
38 \cdot 7 \\
81 \cdot 0 \\
66 \cdot 6(3 \cdot 6)^{*}\end{array}$ & $\begin{array}{c}61 \cdot 5 \\
21 \cdot 6 \\
102 \cdot 6 \\
82 \cdot 8(10 \cdot 8)^{*}\end{array}$ & $\begin{array}{c}27 \cdot 0 \\
0 \\
16 \cdot 2 \\
14 \cdot 4(3 \cdot 6) *\end{array}$ & $\begin{array}{l}234 \cdot 6 \\
163 \cdot 5 \\
331 \cdot 2 * * \\
280 \cdot 8\end{array}$ \\
\hline
\end{tabular}

* Follicles with antra.

$\mathrm{aRG}=$ antiserum to rat gonadotrophin.

$\dagger$ Contains FSH and LH activity.

+ Significantly different from those in control and aRG-treated groups, $P<0.005$.

** Significantly different from control $(P<0.025)$ and aRG-treated $(P<0.005)$ animals.

In the absence of circulating gonadotrophic hormones during the first 10-14 days of life, the development of thecal and granulosa cells is impaired: granulosa cell nuclei are irregular in shape rather than round, and the spaces between the granulosa cells disappear as do the spaces between the granolosa cells and oocyte (Eshkol et al., 1970; Hardy et al., 1974). The most striking structural change due to gonadotrophin deprivation, however, is observed in the zona pellucida, the width of which is diminished and becomes irregular, and the number of cell processes within the zona pellucida is markedly reduced (Hardy et al., 1974). These changes have been attributed to alterations in the structure (e.g. permeability) of the granulosa cell membrane. Substitution with exogenous gonadotrophins after deprivation of the endogenous hormones has indicated that FSH seems primarily responsible for granulosa cell proliferation, and also plays a role in the preservation of the integrity of the granulosa cell membrane (Eshkol et al., 1970). Addition of LH to FSH, however, promotes an enrichment of the thecal layer, an enhancement of vascular development and antrum formation (Eshkol et al., 1970).

Although proliferation of granulosa cells was significantly reduced as a consequence of gonadotrophin deprivation (Table 1), the growth of oocytes 
seemed affected, suggesting that although during the first 2 weeks of postnatal development granulosa cell proliferation is dependent upon gonadotrophin stimulation, this is not the case for oocyte growth (Eshkol et al., 1970). Whether a growing oocyte residing in an abnormal follicular envelope is functionally competent, however, is unknown.

Whereas free oocytes complete meiosis spontaneously, follicle-enclosed rat oocytes explanted before the preovulatory LH surge into a hormone-free medium will remain in the dictyate stage (Tsafriri et al., 1972). Resumption of meiosis can be induced by adding LH to the medium. This finding could imply that LH removes an inhibitory influence exerted on the oocyte by the granulosa cells (Foote \& Thibault, 1969). Some data suggest that the action of LH on ovum maturation is mediated by cyclic AMP (Tsafriri et al., 1972) and involves protein synthesis (Tsafriri et al., 1973). Other evidence suggests that LH may act by stimulating granulosa cell glycolysis or steroidogenesis (Armstrong, 1970). The appearance of a gonadotrophin-induced factor(s) within the oocyte cytoplasm that is essential for normal formation of the male pronucleus is another process which, according to Thibault \& Gérard (1973), is necessary for complete oocyte maturation.

\section{STEROIDOGENESIS}

The steroidogenic capacity of ovaries from 5-14-day-old rats was examined by Quattropani \& Weisz (1973) by incubation techniques. An accurate quantitative assessment of the data must be made with caution since the enzyme systems were not saturated with substrate during the incubations. Nevertheless, the conversion of progesterone to oestradiol was characterized by an increase to a peak at Day 10 followed by a decrease. This rise paralleled the appearance and rapid increase in the amount of interstitial tissue, associated lipid and $3 \beta$ hydroxysteroid activity. Circulating FSH (Quattropani \& Weisz, 1973) and LH (Weisz \& Ferin, 1970) levels also rose during this period. In contrast, there were no morphological or histochemical findings that could be correlated with the decrease in oestradiol formation after Day 10.

Concerning gonadotrophic control of ovarian steroidogenesis, experiments have recently been performed in which the influence of FSH alone was compared with that of $\mathrm{FSH}+\mathrm{LH}$ on steroid biosynthesis in the ovary of the immature 3-week-old mouse (Kraiem \& Samuels, 1974). After stimulation with gonadotrophins in vivo, the major steps between cholesterol and oestrogens were studied by incubating appropriate substrates with ovarian homogenates.

Endogenous and exogenous sources of $\mathrm{LH}$ were neutralized with antisera and it was found that FSH alone acted primarily as a stimulator of general growth: most of the increases in enzyme activity were proportional to the general increase in ovarian protein, and the increase in protein paralleled that of ovarian weight. In contrast, the addition of $\mathrm{LH}$ to FSH elicited not only an increase of steroidogenic enzymes/ovary as had been observed with FSH alone, but also marked differential stimulation of certain enzyme activities/mg protein, particularly 20 $\alpha$-hydroxysteroid dehydrogenase, aromatizing and cholesterol side-chain cleavage systems (Table 2). These are therefore critical 
enzymes of steroid biosynthesis which are particularly responsive to stimulation by the combined gonadotrophic hormones. Since these enzyme activities were slightly increased by FSH alone (Table 2) the investigators proposed that this was compatible with the possibility, strengthened also by data of other studies (Reichert et al., 1968; Koch et al., 1973; Lipner et al., 1974), that some LH activity is an intrinsic attribute of the FSH molecule, as a result perhaps of common amino acid sequences in the $\beta$-subunits.

Table 2. The response of mouse ovaries in vitro to $\mathrm{FSH}$ or $\mathrm{FSH}+\mathrm{LH}$

\begin{tabular}{|c|c|c|c|}
\hline & Control & $F S H$ & $F S H+L H$ \\
\hline $\begin{array}{l}\text { Ovarian wt (mg) } \\
\text { Proteins (mg/ovary) }\end{array}$ & $\begin{array}{l}4 \cdot 1 \\
0 \cdot 18\end{array}$ & $\begin{array}{l}6 \cdot 2 \\
0 \cdot 31\end{array}$ & $\begin{array}{l}12 \cdot 0 \\
0 \cdot 65\end{array}$ \\
\hline $\begin{array}{l}\mathrm{C}_{21} \text { steroids* } \\
\text { (substrate: cholesterol) }\end{array}$ & $0.1(0.02)$ & $0.2(0.06)$ & $1 \cdot 2(0 \cdot 78)$ \\
\hline $\begin{array}{l}\text { 20x-Dihydroprogesterone* } \\
\text { (substrate: progesterone) }\end{array}$ & $46(8 \cdot 3)$ & $82(25 \cdot 4)$ & $1408(915 \cdot 2)$ \\
\hline $\begin{array}{l}\text { Oestradiol }{ }^{*} \\
\text { (substrate: } \Delta^{4} \text {-androstenedione) }\end{array}$ & N.D. & $8(2 \cdot 5)$ & $38(24 \cdot 7)$ \\
\hline
\end{tabular}

N.D., not detectable.

* Metabolite(s) isolated following incubation in vitro of ovarian homogenate. The results are expressed in $\mathrm{pmol}$ steroid/mg protein of ovarian homogenate, and in parentheses as pmol steroid/ovary.

In the above experiments the different ovarian compartments were not separated. Evidence in vitro (Ryan \& Petro, 1966) indicates that the difference in steroidogenic potential between the granulosa and theca cells is quantitative rather than qualitative: whereas granulosa cells, because of weak 17-hydroxylase and 17,20-lyase activities, favour progesterone production and the $\Delta^{4}$ pathway, pregnenolone conversion in theca cells is directed towards androgen and oestrogen formation by the $\Delta^{5}$ pathway. Granulosa cells have a greater ability to aromatize androgens than do thecal cells (Ryan \& Short, 1965). Because of the absence of an adequate blood supply, the granulosa cells in vivo will be poorly supplied with oxygen or other essential nutrients, and hence possibly limited in their ability to synthesize steroids. Once granulosa cells acquire a blood supply and luteinize, their biosynthetic potential can be fully expressed. The oocyte in vivo has also been implicated as being another factor which inhibits steroidogenesis by the granulosa cells. Removal of the oocyte from the preovulatory follicle in the rabbit results in luteinization of the granulosa cells and the secretion of progesterone (El-Fouly et al., 1970). The luteinization-inhibiting influence of the oocyte can be overcome by LH. A possible explanation for this may be that the inhibitory factor associated with the oocyte is inactivated during the process of oocyte maturation, so that when the latter is stimulated by LH the oocyte can no longer suppress luteinization, even though it has not been physically removed from proximity with the granulosa cells.

\section{FOLLIGULAR MATURATION}

It is generally agreed that the first step in the action of gonadotrophic hormones 
is their interaction with specific receptors in the target cells. Recent studies have indicated that the number (or affinity) of specific gonadotrophic receptors in the follicle is intimately related to the stage of follicular maturation. Thus, granulosa cells harvested from large pig follicles bind more HCG (and hence LH, since they appear to share the same receptor) compared to granulosa cells isolated from adjacent small follicles (Channing \& Kammerman, 1973). This probably accounts for the observation that granulosa cells from large follicles, by virtue of sufficient LH bound to receptors, can luteinize spontaneously in culture media devoid of exogenous pituitary hormones, whereas granulosa cells obtained from small follicles do not luteinize even in the presence of exogenous LH (Channing, 1970). Thecal tissue of large follicles also binds more LH/HCG than adjacent small follicles, which may explain why the thecal tissue of large, but not small, follicles is the target for the ovulatory action of LH (Channing \& Kammerman, 1974).

These observations lead to the still unresolved problem of determining the factor(s) controlling which follicle will have the greater abundance (or higher affinity) of $\mathrm{LH}$ and FSH receptors, and therefore which follicle will eventually reach maturity and ovulate. Complex interactions of steroid and polypeptide hormones are probably involved. Steroid hormones not only influence follicular maturation by their effects upon FSH and LH release, but also seem to modulate follicular growth by an intraovarian mechanism.

The results of Goldenberg et al. (1972) and Reiter et al. (1972) have led these workers to propose that gonadotrophin-stimulated production of oestrogen causes increased ovarian uptake of $\mathrm{FSH}$, and hence progressive follicular maturation. The rapid growth of the follicle and rise of oestrogens late in the proliferative phase, when FSH levels are actually decreasing, is consistent with the above findings that the follicle, as it matures, becomes increasingly sensitive to gonadotrophic stimulation as a result of the local effects of oestrogens. While the Graafian follicle grows to full maturity and ovulates, other follicles become atretic. The cause of atresia may be because these follicles, which have not reached the maturational stage of the follicle which will ovulate, are unable to produce adequate local concentrations of oestrogens in order to sustain growth under conditions of declining levels of FSH. Androgens, on the other hand, appear to have an opposite effect to that of oestrogens and apparently inhibit follicular growth (Hoffman \& Meyer, 1965). The local effect of ovarian androgens may therefore play an addition role in promoting follicular atresia.

It is apparent that, in considering follicular growth, it is necessary to take into account not only the stimulation by FSH and LH, but also the stimulatory and inhibitory effects of the intraovarian concentrations of oestrogens and androgens. This serves to illustrate once more the dominating feature of the present, by no means exhaustive discussion: the complexity in regulating follicular function, reflecting the many factors impinging upon it, and underlying the fundamental unity between follicular development and functional competence.

\section{ACKNOWLEDGMENTS}

This study was supported in part by Ford Foundation Grant No 67-470 and 
the World Health Organization. One of us (B.L.) is an Established Investigator of the Chief Scientist's Bureau, Ministry of Health, Israel.

\section{REFERENCES}

Armstrong, D.T. (1970) Reproduction. A. Rev. Physiol. 32, 439-470.

BysKov, A.G. \& LiNTERN-MOoRE, S. (1973) Follicle formation in the immature mouse ovary: the role of the rete ovarii. F. Anat. 116, 207-217.

Bysxov, A.G. \& Rasmussen, G. (1973) Ultrastructural studies of the developing follicle. In The Development and Maturation of the Ovary and its Functions, pp. 55-62. Ed. H. Peters. Excerpta Medica, Amsterdam.

Channing, C.P. (1970) Effects of stage of the estrous cycle and gonadotrophins upon luteinization of porcine granulosa cells in culture. Endocrinology 87, 156-164.

Channing, G.P. \& Kammerman, S. (1973) Characteristics of gonadotropin receptors of porcine granulosa cells during follicle maturation. Endocrinology 92, 531-540.

Channing, C.P. \& Kammerman, S. (1974) Binding of gonadotropins to ovarian cells. Biol, Reprod. 10, 179-198

El-Fouly, M.A., Cook, B., Nekola, M. \& Nalbandov, A.V. (1970) Role of the ovum in follicular luteinization. Endocrinology 87, 288-293.

Eshrol, A., Lunenfeld, B. \& Peters, H. (1970) Ovarian development in infant mice. Dependence on gonadotrophic hormones. In Gonadotrophins and Ovarian Development, pp. 249-258. Eds W. R. Butt, A. C. Crooke \& M. Ryle. Livingstone, Edinburgh.

Foote, W.D. \& Thibault, C. (1969) Recherches expérimentales sur la maturation in vitro des oocyte de truie et de veau. Annls Biol. anim. Biochim. Biophys. 9, 329-349.

Goldenberg, R.L., Vaitukartis, J.L. \& Ross, G.T. (1972) Estrogen and follicle stimulating hormone interactions of follicle growth in rats. Endocrinology 90, 1492-1498.

HARDY, B., DANON, D., EshKol, A. \& LunENFELD, B. (1974) Ultrastructural changes in the ovaries of infant mice deprived of endogenous gonadotrophins and after substitution with FSH. F. Reprod. Fert. 36, 345-352.

Hopfman, F. \& MeYer, C. (1965) U'ber die Wirkung der Androgene auf die Follikel Reifung und die Corpus Luteum Bildung der Frau bei intraovarieller Applikation. Geburtsh. Frauenheilk. 25, 11321139.

Koch, Y., Zor, U., Pomerantz, S., Chobsieng, P. \& Lindner, H.R. (1973) Intrinsic stimulatory action of follicle-stimulating hormone on ovarian adenylate cyclase. F. Endocr. 58, 677-678.

KraIem, Z. \& SAmuels, L.T. (1974) The influence of FSH and FSH + LH on steroidogenic enzymes in the immature mouse ovary. Endocrinology 95, 660-668.

Krarup, T., Pedersen, T. \& Faber, M. (1969) Regulation of oocyte growth in the mouse ovary. Nature, Lond. 224, 187-188.

LAMprecht, S.A., Zor, U., Tsafriri, A. \& Lindner, H.R. (1973) Action of prostaglandin $E_{2}$ and of luteinizing hormone on ovarian adenylate cyclase, protein kinase and ornithine decarboxylase activity during postnatal development and maturity in the rat. F. Endocr. 57, 217-233.

Lipner, H., Hirsch, M.A., Moudgal, N.R., MacDonald, G.J., Ying, S-Y. \& Greep, R.O. (1974) Ovulating-inducing activity of FSH in the rat. Endocrinology 94, 1351-1358.

LuNENFELD, B. \& EshKOL, A. (1970) Immunology of follicle-stimulating hormone and luteinizing hormone. Vitams Horm. 27, 131-197.

Pedersen, T. (1969) Follicle growth in the immature mouse ovary. Acta endocr., Copenh. 62, 117-132.

Pedersen, T. (1972) Follicle growth in the mouse ovary. In Oogenesis, pp. 361-376. Eds J. D. Biggers \& A. W. Schuetz. University Park Press, Baltimore.

Peters, H., Byskov, A.G. \& Faber, M. (1973) Intraovarian regulation of follicle growth in the immature mouse. In The Development and Maturation of the Ovary and its Functions, pp. 20-23. Ed. H. Peters. Excerpta Medica, Amsterdam.

QuatTropan, S.L. \& Weisz, J. (1973) Conversion of progesterone to estrone and estradiol in vitro by the ovary of the infantile rat in relation to the development of its interstitial tissue. Endocrinology 93, $1269-1276$.

Reichert, L.E., JR, Kathan, R.H. \& Ryan, R.J. (1968) Studies on the composition and properties of immunochemical grade human pituitary follicle stimulating hormone (FSH): comparison with luteinizing hormone (LH). Endocrinology 82, 109-114.

Reiter, E.O., Goldenberg, R.L., Vartukaitis, J.L. \& Ross, G.T. (1972) A role for endogenous estrogen in normal ovarian development in the neonatal rat. Endocrinology 91, 1537-1539.

Ryan, K.J. \& Petro, S. (1966) Steroid biosynthesis by human ovarian granulosa and thecal cells. 7. clin. Endocr. Metab. 26, 46-52. 
RYAN, K.J. \& SHORT, R.V. (1965) Formation of estradiol by granulosa and theca cells of the equine ovarian follicle. Endocrinology 76, 108-114.

SCHNEIDER, L.G. \& BEN-OR, S. (1973) The effect of HMG and FSH on amino acid incorporation in the developing ovary as a function of age. In The Development and Maturation of the Ovary and its Functions, pp. 38-48. Ed. H. Peters. Excerpta Medica, Amsterdam.

STEGNER, H.E., LuNENFELd, B. \& EshKol, A. (1970) Ultra-structural ovarian changes after deprivation of endogenous gonadotrophins and the effect of FSH and HMG in the deprived immature animals. In Gonadotrophins and Ovarian Development, pp. 259-265. Eds W. R. Butt, A. C. Crooke \& M. Ryle. Livingstone, Edinburgh.

Thibault, C. \& Gerard, M. (1973) Cytoplasmic and nuclear maturation of rabbit oocytes in vitro. Annls Biol. anim. Biochim. Biophys. 13, Suppl. 145-156.

Tsafriri, A., LindNER, H.R., Zor, U. \& LAMPRecht, S.A. (1972) In vitro induction of meiotic division in follicle-enclosed rat oocytes by LH, cyclic AMP and prostaglandin $\mathrm{E}_{2}$. F. Reprod. Fert. 31, 3950 .

Tsafriri, A., Lieberman, M.E., Barnea, A., Bauminger, S. \& Lindner, H. (1973) Induction by luteinizing hormone of ovum maturation and of steroidogenesis in isolated graafian follicles of the rat: role of RNA and protein synthesis. Endocrinology 93, 1378-1386.

WeIsz, J. \& Ferin, M. (1970) Pituitary gonadotrophins and circulating LH in immature rats-a comparison between normal females and males and females treated with testosterone in neonatal life. In Gonadotrophins and Ovarian Development, pp. 339-350. Eds W. R. Butt, A. C. Crooke \& M. Ryle. Livingstone, Edinburgh.

Witschi, E. (1963) Embryology of the ovary. In The Ovary, pp. 1-10. Eds H. G. Grady \& D. E. Smith. Williams \& Wilkins, Baltimore. 